\title{
Analisis Studi Kelayakan Usaha Air Minum Berbasis Chlorine Dioxide pada Unit Usaha BUMDes Kertajaya
}

\author{
Lidya Agustina ${ }^{1 *}$, Hanny ${ }^{2}$, Lauw Tjun Tjun ${ }^{3}$, Debbianita ${ }^{4}$, Joni ${ }^{5}$, Feren \\ Farah Focket Batistuta ${ }^{6}$ \\ 1,2,3,4,5,6Program Studi Akuntansi, Fakultas Ekonomi, Universitas Kristen \\ Maranatha \\ Email: lidya_kho@yahoo.com¹, sevenhanny@gmail.com², \\ lauwtjuntjun@yahoo.co.id ${ }^{3}$,debbianita@gmail.com ${ }^{4}$,jonivendi@yahoo.com ${ }^{5}$, \\ ferenfarahpocket@gmail.com ${ }^{6}$ \\ *Corresponding author: lidya_kho@yahoo.com ${ }^{1}$
}

\begin{abstract}
ABSTRAK
Badan Usaha Milik Desa (BUMDes) Kertajaya melalui Pengelolaan Air Bersih (PAB) Tirta Jaya memiliki usaha penyaluran air bersih, namun daya dorong ekonomi yang dihasilkan dari usaha penyaluran air bersih masih sangat rendah sehingga keberadaan BUMDes untuk dapat memakmurkan masyarakat desa Kertajaya masih jauh dari harapan. Dalam pengabdian masyarakat ini, kami berupaya untuk meningkatkan nilai tambah dari usaha yang ada sebelumnya. Peningkatan nilai tambah ekonomi dapat dilakukan dengan mengembangkan usaha penyaluran air bersih menjadi usaha penyaluran air minum yang berbasis Chlorine Dioxide. Untuk mengetahui minat, kepercayaan, serta tanggapan masyarakat Desa Kertajaya terhadap usaha penyaluran air minum yang berbasis Chlorine Dioxide, maka kami mengevaluasi studi kelayakan bisnis usaha penyaluran air minum pada BUMDes Kertajaya dengan memperhatikan Aspek Pasar; Teknis dan Teknologi; Keuangan; Ekonomi/Sosial dan Politik; Lingkungan Hidup; Hukum dan Legalitas usaha penyaluran air minum. Hasil studi kelayakan bisnis berdasarkan aspek pasar, teknis \& teknologi, keuangan, serta ekonomi menunjukkan bahwa usaha penyaluran air minum berbasis Chlorine Dioxide layak untuk dijalankan di Desa Kertajaya. Hasil studi kelayakan bisnis ini dapat memberikan masukan mengenai prospek usaha penyaluran air minum bagi BUMDes Kertajaya.
\end{abstract}

Kata Kunci: Studi kelayakan bisnis; usaha air minum; BUMDes; Chlorine Dioxide.

\section{ABSTRACT}

Kertajaya Village-Owned Enterprises (BUMDes) through Tirta Jaya Clean Water Management (PAB) has a clean water distribution business, but the economic driving force generated from the clean water distribution business is still very low so that the existence of BUMDes to be able to prosper the Kertajaya village community is still far from expectation . In this community service, we strive to increase added value from existing businesses. Increasing the added value of the economy can be done by developing a clean water supply business to distribute drinking water based on chlorine dioxide. To find out the interest, trust, and response of the Kertajaya Village community to the Chlorine Dioxide-based drinking water distribution business, we evaluated a feasibility study for the business of distributing drinking water to BUMDes Kertajaya by paying attention to Market Aspects; Technical and Technology; Finance; Economic / Social and Political; Environment; Law and legality of drinking water distribution business. The results of a business feasibility study based on market, technical \& technological, financial, and economic aspects show that the Chlorine Dioxide-based drinking water distribution business is feasible to run in Kertajaya Village. The 
results of this business feasibility study can provide input on the business prospects for distributing drinking water for BUMDes Kertajaya.

Keywords: Business feasibility study; drinking water business; BUMDes; Chlorine Dioxide.

\section{PENDAHULUAN}

Desa Kertajaya adalah sebuah desa yang berlokasi di Cianjur, Jawa Barat. Pada tahun 2017, Desa ini dihuni oleh 8.916 orang penduduk. Berdasarkan data tahun 2014, desa ini memiliki 2.209 Kepala Keluarga (KK). Adapun Kepala Desa Kertajaya adalah Bapak Sunandar. Desa tersebut memiliki tanah pertanian seluas 192.44 hektar dari 382.44 hektar luas keseluruhan wilayah desanya (Hanny et al., 2020). Pada tahun 2014, Kepala Desa Kertajaya mendirikan Badan Usaha Milik Desa (BUMDes). Struktur organisasi BUMDes Kertajaya meliputi seorang ketua BUMDes, seorang sekretaris, seorang bendahara dan seorang anggota BUMDes.

Pada kegiatan pengabdian masyarakat periode sebelumnya, telah dilakukan pemetaan masalah dan potensi BUMDes Kertajaya, dimana hasilnya menunjukkan bahwa sumber air bersih merupakan potensi besar yang dimiliki BUMDes Kertajaya dan potensi ini telah dimanfaatkan untuk memenuhi kebutuhan air bersih masyarakat dengan kapasitas sekitar 387 Kepala Keluarga (KK) (Hanny et al., 2020). Pemanfaatan sumber air bersih pada Desa Kertajaya dikoordinir oleh unit usaha air pada BUMDes Kertajaya melalui PAB Tirta Jaya. Akan tetapi daya dorong ekonomi yang dihasilkan dari usaha penyaluran air bersih masih sangat rendah sehingga keberadaan BUMDes masih jauh dari harapan sebagai pilar kesejahteraan bangsa yang mendukung kehidupan desa otonom berdasarkan UndangUndang yang mengatur tentang desa. (Undang-Undang Republik Indonesia Nomor 6 Tahun 2014). Hal ini merupakan masalah utama yang dialami oleh BUMDes Kertajaya di dalam menjaga keberlangsungan usaha air yang ada.

Potensi PAB Tirta Jaya untuk mengembangkan usahanya di bidang penyediaan air bersih cukup tinggi khususnya dalam hal bahan baku (air) dan kondisi pemasarannya. Dalam kegiatan pengabdian masyarakat ini, 
kami berupaya untuk meningkatkan nilai tambah dari usaha yang ada sebelumnya. Upaya peningkatan nilai tambah ekonomi ini dapat dilakukan dengan cara mengembangkan usaha penyaluran air bersih menjadi usaha penyaluran air minum yang berbasis Chlorine Dioxide. Air minum berbasis Chlorine Dioxide dipilih karena dapat mengubah air bersih menjadi air minum (Hamdani, 2019), serta berdasarkan penelitian awal yang kami lakukan, Chlorine Dioxide dapat mengubah air bersih menjadi air minum secara efisien, efektif, dan ramah lingkungan. Air minum berbasis Chlorine Dioxide juga telah diaplikasikan di banyak negara dalam berbagai kebutuhan dari mulai kebutuhan rumah tangga sampai pada kebutuhan industri.

Untuk mengetahui minat, kepercayaan dan respon masyarakat Desa Kertajaya terhadap usaha penyaluran air minum yang berbasis Chlorine Dioxide, maka pengabdian masyarakat ini dilaksanakan dengan tujuan untuk mengevaluasi kelayakan bisnisnya melalui studi kelayakan bisnis berdasarkan Aspek Pasar; Teknis dan Teknologi; Keuangan;
Ekonomi/Sosial dan Politik; Lingkungan Hidup; Hukum dan Legalitas usaha penyaluran air minum pada BUMDes Kertajaya. Hasil studi kelayakan bisnis diharapkan dapat menjadi masukan tentang prospek usaha yang mendukung pertimbangan BUMDes untuk mengembangkan unit usaha yang saat ini dimiliki BUMDes Kertajaya.

\section{METODE PENELITIAN}

Pada tahun 2019, Prodi Akuntansi Universitas Kristen Maranatha melakukan pengabdian masyarakat di Desa Kertajaya, dimana fokus dari pengabdian masyarakat ini adalah membantu BUMDes Kertajaya dalam upaya pengembangan PAB Tirtajaya. Pengabdian masyarakat ini dilakukan oleh para dosen dan mahasiswa dari Program Studi Akuntansi Universitas Kristen Maranatha bekerjasama dengan Perusahaan Pesona Scientific yang memiliki hak/izin atas distribusi Chlorine Dioxide di Indonesia. Pengabdian masyarakat ini bertujuan untuk menggambarkan (deskriptif) melalui observasi dan pengumpulan data di lapangan dengan metode survei sebagai metode pengumpulan 
datanya. Objek dalam pengabdian masyarakat ini adalah Desa Kertajaya, Kecamatan Ciranjang, Kabupaten Cianjur, Provinsi Jawa Barat. Sedangkan yang menjadi subjeknya adalah 1.876 kepala keluarga yang merupakan masyarakat desa Kertajaya selaku konsumen dari usaha penyaluran air minum.

Data yang akan dianalisis adalah data primer dan sekunder. Data primer dikumpulkan dan dianalisis terkait dengan aspek non keuangan yang berhubungan dengan lingkungan eksternal dan internal seperti manajemen BUMDes, kondisi perekonomian masyarakat Desa Kertajaya, minat masyarakat, daya beli masyarakat, dan kepercayaan masyarakat dengan air minum yang akan disalurkan BUMDes Kertajaya. Sedangkan data sekunder dalam merupakan data yang telah dipublikasikan, juga dihimpun dalam pengabdian ini. Selanjutnya berdasarkan data primer maupun sekunder yang terkumpul akan diolah dan dianalisis secara deskriptif, sehingga dapat diperoleh kesimpulan hasil analisis mengenai kelayakan usaha penyaluran air minum pada BUMDes Kertajaya.

\section{HASIL DAN PEMBAHASAN}

Dalam mendirikan sebuah usaha, studi kelayakan bisnis (feasibility study) merupakan langkah awal yang tepat untuk dilakukan demi menilai kelayakan sebuah usaha untuk didirikan dan dijalankan (Sofiah \& Septiana, 2017). Hasil dari analisis kelayakan sebuah bisnis dapat dijadikan sebagai dasar pertimbangan bagi investor dalam menilai risiko dan kondisi di masa depan jika usaha tersebut dijalankan (Muqorobin, 2018). Dengan demikian, hasil analisis dari studi kelayakan bisnis ini dapat membantu calon pelaku usaha untuk menghindari/mencegah hal yang tidak diharapkan terjadi saat mereka menjalankan usahanya (Sofiah \& Septiana, 2017), bahkan hasil analisis kelayakan bisnis ini mampu memberikan keyakinan lebih bagi investor bahwa usaha yang hendak dijalankan ini memang memberikan nilai bagi organisasinya dan mampu bersaing dalam dunia usaha (Muqorobin, 2018). 
Studi kelayakan bisnis (feasibility study) terdiri dari beberapa aspek yang harus dianalisis untuk menghasilkan informasi kelayakan dari pendirian sebuah usaha/bisnis. Aspek-aspek yang tercakup dalam studi kelayakan bisnis dan akan dianalisis dalam kegiatan pengabdian masyarakat ini meliputi aspek pasar dan pemasaran (Tanaka \& Marlina, 2017; Bintoro, 2014), aspek teknis dan teknologi (Tanaka \& Marlina, 2017), aspek keuangan (Tanaka \& Marlina, 2017), aspek ekonomi, sosial, dan politik (Fitriani, Sudono, \& Handyastuti, 2018), aspek lingkungan hidup (Munir, Saraswati, H, \& Rifa'i, 2019), aspek hukum dan legalitas (Tanaka \& Marlina, 2017).

\section{Aspek Pasar dan Pemasaran}

Aspek pemasaran dianalisis untuk mengetahui potensi, peluang dan strategi pemasaran jika produk usaha yang hendak dijalankan telah diluncurkann di kemudian hari (Bintoro, 2014).

\section{Analisis aspek pasar pada}

Desa Kertajaya menunjukkan bahwa mayoritas penduduk desa Kertajaya memiliki pendapatan lebih kecil atau sama dengan Rp.2.336.004,- per keluarga untuk setiap bulannya. Berdasarkan hasil survei pasar, data menunjukkan bahwa lebih dari 45\% keluarga di desa Kertajaya tidak memiliki kebiasaan merebus air untuk memenuhi kebutuhan air minumnya.

Analisis aspek pemasaran dari rencana pendirian usaha air minum berbasis Chlorine Dioxide di BUMDes Kertajaya atas 119 Kepala Keluarga (KK) selaku sampel survei menunjukkan hasil sebagai berikut:

\section{a. Potensi Pasar}

- Sebanyak $52,1 \%$ dari responden dapat menjadi calon pasar yang potensial jika dilihat dari kebiasaan mereka mengkonsumsi air putih.

- Sebanyak 88,24\% responden menunjukkan minatnya untuk beralih ke produk air minum baru. Hanya $\quad 11,76 \%$ responden menyatakan untuk tetap memilih produk air minum yang mereka gunakan saat ini. Pada dasarnya, penduduk Kertajaya terbuka terhadap produk baru. Namun demikian, loyalitas pasar terhadap suatu produk tetap tinggi. Lebih dari $72 \%$ responden menyatakan untuk setia menggunakan produk yang sama sejauh kualitas produk 
tetap terjaga dan harganya pun tetap terjangkau.

- Toleransi pasar dalam hal kepuasan produk berada di level menengah. Sebanyak 78\% dari responden menyatakan bahwa saat mereka tidak merasa puas akan perbandingan harga dan kualitas produk maka mereka masih memiliki kemauan untuk memberikan masukan kepada produsen.

- Jika keluhannya tidak ditanggapi dengan perubahan/solusi yang baik maka mereka akan beralih ke produk lainnya.

- Mayoritas pengguna air isi ulang/gallon membutuhkan 1 hingga 3 gallon/minggu (63\% dari responden). Dengan demikian, kebutuhan rata-rata pengguna air isi ulang/gallon adalah sebanyak 3,3 gallon/minggu.

\section{b. Tantangan Pasar}

- Beberapa Produk Air Minum Mineral kemasan telah memasuki pasar dimana merk air minum mineral yang memimpin pasar adalah Aqua (29,85\%)
- Pasar cukup sensitif terhadap harga produk. Mereka lebih memilih produk dengan harga lebih murah daripada produk yang telah lolos dari uji laboratorium dengan harga yang lebih mahal. (57\% responden)

- Sebanyak $47 \%$ responden lebih memilih meminum air selain air mineral (spt kopi, sirup, air teh, minuman ringan).

\section{c. Strategi Pasar.}

- Potensi jumlah KK pelanggan air minum $=2209 \mathrm{KK}$

- Konsumen Air Bersih Tirtajaya 1 per $2018=387$ pelanggan dengan persediaan air maksimum untuk 1000 pelanggan.

- Harga Ideal berdasarkan survei potensi pasar adalah Rp.3.000,per gallon.

\section{Aspek Teknis dan Teknologi}

Aspek ini merupakan aspek yang berkaitan dengan pembangunan unit usaha secara fisik dan juga termasuk perihal penggunaannya setelah bangunan fisik selesai (Kamaluddin, 2004 dalam (Afiyah, Saifi, \& Dwiatmanto, 2015). Ada beberapa hal 
yang perlu ditentukan dari aspek teknis dan teknologi ini, yakni mengenai: kesiapan teknologi (dalam produksi termasuk teknologi desain produk), lokasi dan distribusi, serta tata letak alat (layout) produksi (Purnomo, Riawan, \& Sugianto, 2017).

Rencana konsep produk dalam usaha ini adalah air minum isi ulang per gallon dengan spesifikasi air tanah yang dimurnikan dengan tablet Chlorine Dioxide, tablet ini bermerk Ecosys dan telah direkomendasikan oleh: WHO, FDA, EPA, FAD, USDA, FSIS, NASA, HACCP, JECFA. Dosis penggunaan Ecosys Tablet untuk air minum adalah satu (1) tablet (4 gram) dapat digunakan untuk 550 liter air (konsentrasi 0,8 ppm). Sebelumnya, air tanah yang akan digunakan untuk air minum isi ulang diuji kelayakannya di laboratorium (Uji Baku Mutu).

\section{Berdasarkan} kapasitas produksi dan jam kerja maka target produksi sebanyak 80 gallon per hari, hal ini dengan asumsi waktu pengisian 5 menit untuk setiap pengisian gallon, asumsi proses pembayaran 1 menit per konsumen. Mengingat proyeksi kebutuhan air gallon (dengan tingkat keyakinan menengah atau wajar) sebanyak 188 gallon per hari dan volume produksi 82,5 gallon per hari maka peralatan produksi (toren) dan Sumber Daya Manusianya dapat dikembangkan saat usaha air minum mulai berjalan.

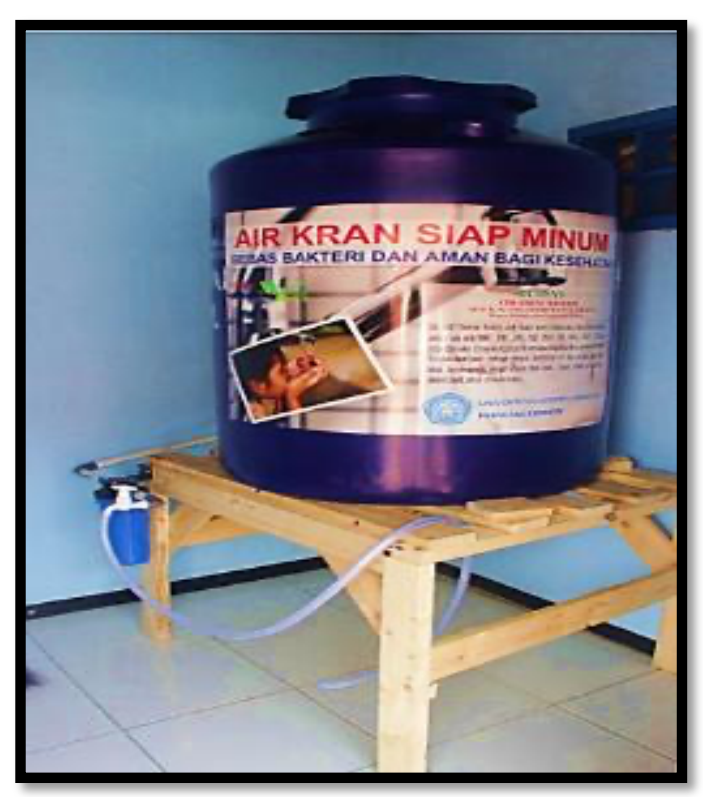

Gambar 1: Tata Letak Produksi

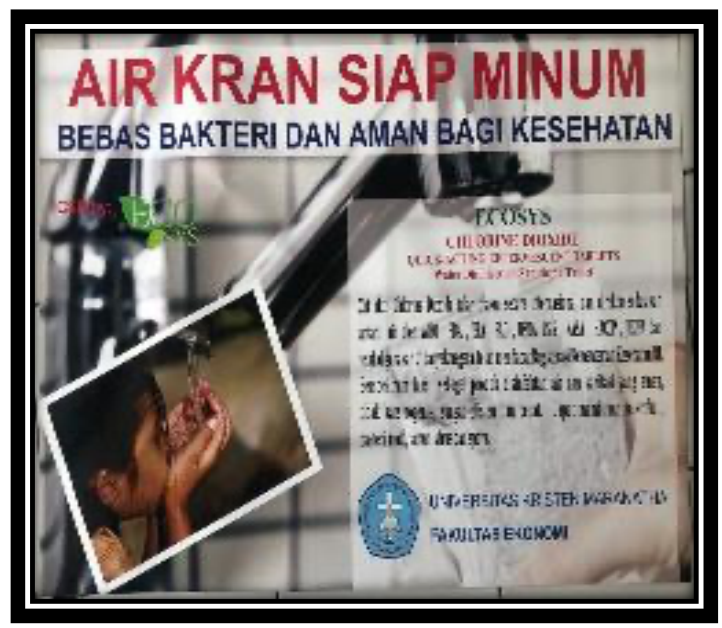

Gambar 2: Rancangan Label Produksi 


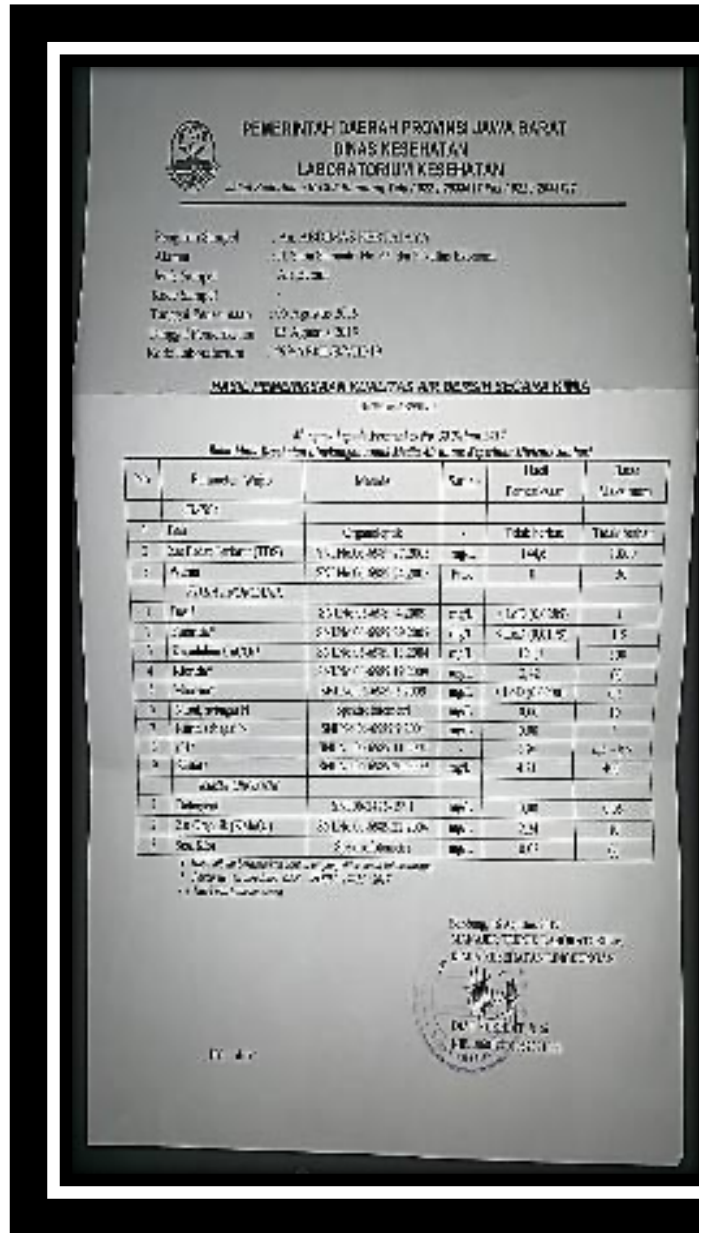

Gambar 3: Hasil Uji Baku Mutu

Kesehatan Lingkungan Untuk Media

Air Keperluan Higienis Sanitasi

\section{Aspek Keuangan}

Untuk menganalisis kelayakan usaha dari aspek keuangan/finansial, analisis yang dapat dilakukan adalah analisis Pay Back Period, analisis NPV (Net Present Value) ataupun analisis Internal Rate of Return (Tanaka \& Marlina, 2017; Fitriani et al., 2018), selain disajikan pula
Analisis Net Benefit/Cost dan Analisis BEP (Break Event Point).

Tabel 1. Data Proyeksi Pendapatan Usaha Air Minum Berbasis Chlorine Dioxide

\begin{tabular}{|lr|}
\hline \multicolumn{1}{|c|}{ DESKRIPSI } & $\begin{array}{r}\text { Kondisi Saat ini } \\
\text { (2.240 gallon } \\
\text { per bulan) } \\
\text { (dllm Rp) }\end{array}$ \\
\hline Pendapatan: & \\
Pendapatan: (75\% x @Rp.3.000,-) x 80 & \\
gallon x 7 hari x 4 minggu & $5,040,000$ \\
Penjualan: Rp.35000 x 100 pcs & $3,500,000$ \\
\multicolumn{1}{|c|}{ Total Pendapatan } & $8,540,000$ \\
\hline Biaya: $\quad$ & \\
Biaya Air Rp.500/m3 & \\
Biaya Listrik & 112,500 \\
Biaya Pegawai (2 Orang) & 500,000 \\
Biaya Bensin (Rp.10.000,- per hari) & $1,500,000$ \\
Biaya Tutup Galon dan Tissue @Rp.260,- & 280,000 \\
Biaya Pulsa & 582,400 \\
Penyusutan Peralatan & 150,000 \\
Pembelian Galon: Rp.35000 x 100 pcs & 50,000 \\
Alokasi untuk uji ulang baku mutu air & $3,500,000$ \\
(uji ulang: 1 thn sekali) & 70,000 \\
\hline Laba Per Bulan sebelum Pajak & $6,744,900$ \\
\hline
\end{tabular}

Analisis aspek keuangan atas rencana pendirian usaha air minum berbasis Chlorine Dioxide di BUMDes Kertajaya meliputi biaya investasi awal sebesar Rp 6.437.000 yang terdiri atas peralatan usaha, perlengkapan usaha, biaya uji baku mutu dan uji E. coli, serta biaya yang 
dikeluarkan untuk pemasangan.

Tabel 1. Menunjukkan laba sebelum pajak Rp 1.795.100 per bulan (berdasarkan hasil survei, unit usaha diperkirakan dapat menjual 80 gallon per hari).

Tabel 2. Analisis Payback Period

\begin{tabular}{|c|c|}
\hline DESKRIPSI & $\begin{array}{l}\text { Kondisi Saat } \\
\text { ini (2.240 } \\
\text { gallon per } \\
\text { bulan) (dlm } \\
\text { Rp) }\end{array}$ \\
\hline \multicolumn{2}{|l|}{ Pendapatan: } \\
\hline Pendapatan: (75\% x @Rp.3.000,-) x 80 & $5,040,000$ \\
\hline Penjualan: Rp. 35000 x 100 pcs & $3,500,000$ \\
\hline Total Pendapatan & $8,540,000$ \\
\hline \multicolumn{2}{|l|}{ Biaya: } \\
\hline Biaya Air Rp.500/m3 & 112,500 \\
\hline Biaya Listrik & 500,000 \\
\hline Biaya Pegawai (2 Orang) & $1,500,000$ \\
\hline Biaya Bensin (Rp.10.000,- per hari) & 280,000 \\
\hline Biaya Tutup Galon dan Tissue @Rp.260,- & 582,400 \\
\hline Biaya Pulsa & 150,000 \\
\hline Pembelian Galon: 100 pcs x Rp.35.000,- & $3,500,000$ \\
\hline $\begin{array}{l}\text { Alokasi untuk uji ulang baku mutu air (uji } \\
\text { ulang: } 1 \text { thn sekali) }\end{array}$ & 70,000 \\
\hline Total Pengeluaran & $6,694,900$ \\
\hline Arus Masuk Cash Bersih per Bulan & $1,845,100$ \\
\hline
\end{tabular}

$$
\begin{aligned}
\text { Payback Period } & =\frac{R p \cdot 6 \cdot 437 \cdot 000,-}{R p \cdot 1 \cdot 845 \cdot 100,-} \\
& =3,5 \text { bulan }
\end{aligned}
$$

Tabel 2. menunjukkan hasil perhitungan arus kas masuk per bulan guna menghitung payback period dari usaha air minum. Payback Period diukur dengan membandingkan investasi awal dengan arus kas masuk bersih per bulan, maka durasi pengembalian investasi awal yang berasal dari keuntungan usaha dapat dipenuhi dalam kurun waktu 3,5 bulan.

$$
\begin{aligned}
& \text { BEP dalam Unit }=\frac{\text { Total Kos Tetap }+ \text { Laba }}{\text { Margin Kontribusi } / \text { unit }} \\
& \text { BEP dalam Unit }=\frac{R p \cdot 1.770 .000,-+0}{R p \cdot 1.591,-} \\
& =1.113 \text { gallon per bulan atau } \\
& =39,75 \text { gallon/hari (dibulatkan) } \rightarrow 40 \\
& \text { gallon/hari }
\end{aligned}
$$

Hasil perhitungan Break Even Point unit usaha air minum BUMDes Kertajaya akan terjadi jika mereka mampu menjual produk sekurangkurangnya 40 gallon per hari dan disarankan untuk menjual produk di atas 40 gallon/hari jika bertujuan untuk memperoleh laba. Dengan menjual produk di bawah 40 gallon/hari, maka perusahaan akan mengalami defisit atau kerugian karena pemasukan mereka tidak dapat menutupi pengeluaran tetapnya secara keseluruhan. 
4. Aspek Ekonomi, Sosial dan Politik

Analisis studi kelayakan bisnis dari aspek ekonomi dapat menggunakan data makroekonomi, sedangkan dari aspek sosial, peneliti harus menganalisis potensi usaha untuk memberikan kontribusi secara sosial (memenuhi tanggung jawab sosialnya) disamping memperoleh laba usaha. Selain aspek sosial dan ekonomi, analisis dari sisi politik dan pengaruhnya terhadap going concern (keberlangsungan) usaha saat dibangun perlu dilakukan (Fitriani et al., 2018).

Analisis aspek Ekonomi, Sosial dan Politik atas rencana pendirian usaha air minum berbasis Chlorine Dioxide di BUMDes Kertajaya adalah sebagai berikut:

- Usaha Air Minum Kemasan (Gallon) ini berpotensi untuk membuka lapangan pekerjaan baru (saat ini masih dapat menggunakan SDM paruh waktu)

- Usaha Air Minum Kemasan (Gallon) ini akan menggunakan SDM dari masyarakat local
- Dengan Usaha Air Minum Kemasan (Gallon) ini, maka usaha ini dapat mendukung industri lainnya, seperti industri kuliner atau penginapan yang lebih higienis dan efisien sehingga daya saing industri lainnya tersebut dapat meningkat.

- Dengan adanya Usaha Air Minum Kemasan (Gallon) ini, maka SDM yang terlibat memiliki kesempatan untuk mendapatkan pelatihan dan pengetahuan baru (investasi SDM)

- Hambatan dalam bidang ekonomi: saat ini, prediksi laba badan usaha ini belum mampu memberikan honor sebesar UMR sehingga belum dapat menggunakan tenaga tetap.

\section{Aspek Lingkungan Hidup}

Kemajuan dunia industri dan kemajuan teknologi memang sangat membantu dalam upaya peningkatan kesejahteraan manusia, namun sebelum melakukan menjalankan usaha, studi kelayakan bisnis dari aspek lingkungan hidup perlu 
dilakukan untuk memastikan bahwa usaha yang dijalankan tidak berdampak buruk pada lingkungan hidup sekitarnya. Dalam analisis ini, dampak usaha terhadap lingkungan hidup akan dikaji (Munir et al., 2019). Analisis ini seringkali dikenal dengan sebutan Analisis Mengenai Dampak Lingkungan (AMDAL). Payung hukum mengenai aspek lingkungan hidup di Indonesia diatur oleh Undang-Undang (UU) Perlindungan dan Pengelolaan Lingkungan Hidup (Undang-Undang Republik Indonesia Nomor 32 Tahun 2009).

Analisis aspek lingkungan hidup atas rencana pendirian usaha air minum berbasis Chlorine Dioxide di BUMDes Kertajaya adalah sebagai berikut:

- Usaha Air Minum gallon ini telah memperhatikan Baku Mutu dari Bahan Baku (Air) dan pengujian aspek Lingkungan Hidup.

- Dengan menggunakan tablet Ecosys, usaha ini justru mendukung pengadaan air bersih dengan proses yang ramah lingkungan.
- Berkaitan dengan penggunaan air bersih dari alam, sisi tanggung jawab sosial berupa pemeliharaan ketersediaan air bersih di perusahaan ini belum terlihat jelas.

\section{Aspek Hukum dan Legalitas}

Menurut Chaidir (2018), ada beberapa hal yang dapat dijadikan sebagai dasar penilaian kelayakan bisnis/usaha jika dinilai dari aspek hukum/legalitasnya, yakni:

- Badan hukum yang paling sesuai untuk dijadikan status badan usaha yang akan didirikan tersebut. PAB Tirtajaya masih merupakan usaha swadaya kategori UMKM, namun demikian akan lebih baik jika sejak dini usaha air minum ini ditentukan bentuk usahanya, misalnya: PT, CV, dll.

- Legalitas komoditas yang dijual oleh perusahaan $\rightarrow$ untuk memastikan bahwa setiap komoditas unit usaha tersebut adalah komoditas yang tidak dilarang oleh Undang-Undang. Kepatuhan dalam menjalankan usahanya 
dievaluasi untuk memastikan bahwa cara pelaku bisnis menjalankan usahanya tidak bertentangan dengan hukum agama.

- Keberadaan ijin usaha dari instansi/departemen ataupun dinas yang berwenang.

Berdasarkan Keputusan Menteri Perindustrian dan Perdagangan Republik Indonesia nomor 651/MPP/ Kep/10/2004 (Menteri Perindustrian dan Perdagangan RI, 2004):

- Unit usaha air minum BUMDes Kertajaya perlu memiliki Tanda Daftar Industri (TDI) dan Tanda Daftar Usaha Perdagangan (TDUP)

- Unit usaha air minum BUMDes Kertajaya perlu memiliki Surat Jaminan Pasok Air Baku dari PDAM dan Ijin Pengambilan Air dari instansi yang berwewenang

- Unit usaha air minum BUMDes Kertajaya perlu memiliki hasil uji air minum dari laboratorium yang telah ditunjuk oleh pemerintah kabupaten/kota atau yang terakreditasi.

- Unit usaha air minum BUMDes Kertajaya perlu untuk memperhatikan larangan dalam hal menyediakan stok air minum dalam wadah siap jual serta belum diperbolehkan untuk mencantumkan merk pada kemasan

\section{SIMPULAN}

Berdasarkan hasil dan pembahasan yang telah dijelaskan sebelumnya, maka dapat disimpulkan bahwa berdasarkan analisis pasar dan pemasaran untuk usaha air minum cukup baik mengingat hampir setengah penduduk mulai menggunakan air minum isi ulang gallon sehingga tidak merebus air minumnya. Sikap pasar terhadap produk baru sangat terbuka namun disertai dengan tingkat loyalitas yang tinggi. Hal yang perlu diperhatikan adalah harga air minum di daerah tersebut cukup elastis karena masyarakat sangat menekankan faktor harga produk daripada kualitas air. 
Berdasarkan analisis produksi menyatakan kapasitas teoritis produksi belum memenuhi kebutuhan pasar. Selanjutnya dari sisi keuangan dan ekonomi, usaha air minum ini berpotensi memberikan laba bagi pengembangan dan mendukung pembangunan ekonomi masyarakat setempat. Berdasarkan aspek lingkungan, analisis studi kelayakan usaha menunjukkan bahan baku mutu dan pengelolaan air di badan usaha ini didesain untuk ramah lingkungan namun belum ada sistem pemeliharaan ketersediaan air bersih yang memadai. Sedangkan dari analisis aspek legal menunjukkan bahwa unit usaha air minum BUMDes Kertajaya belum menentukan bentuk usaha yang formal dan terdapat beberapa ketentuan hukum yang belum terpenuhi.

Hasil studi kelayakan bisnis yang kami lakukan, selanjutnya dapat digunakan oleh BUMDes Kertajaya melalui PAB Tirtajaya untuk membuka unit usaha baru, yaitu usaha air minum isi ulang dalam bentuk gallon. Unit usaha baru tersebut diharapkan dapat meningkatkan pendapatan BUMDes Kertajaya, sehingga BUMDes Kertajaya dapat memenuhi pencapaian target pendapatan yang ditetapkan oleh Desa Kertajaya.

\section{DAFTAR PUSTAKA}

Afiyah, A., Saifi, M., \& Dwiatmanto. (2015). Analisis Studi Kelayakan Usaha Pendirian Home Industry (Studi Kasus pada Home Industry Cokelat "Cozy" Kademangan Blitar). Jurnal Administrasi Bisnis (JAB), 23(1), 1-11.

Bintoro, A. (2014). Studi Kelayakan Produk Baru: BAN 12.00 R24 di PT GTR. Jurnal PASTI, VIII(1), 122-141.

Chaidir. (2018). Aspek-Aspek Studi Kelayakan. Retrieved from PT. Grapadi Sejahtera Mandiri website:

http://grapadimedan.com/2018/

05/10/aspek-aspek-studikelayakan/

Fitriani, I. N., Sudono, A., \& Handyastuti, I. (2018). Studi Kelayakan Bisnis Bakso Lotus Jembar. Gastronomy Tourism Journal, 5(1), 1-11.

Hamdani, L. (2019). Pra Rancangan Pabrik Klorin Dioksida dengan Proses Senior Vibe Preseident (SVP) Kapasitas 30.000 Ton/Tahun. Universitas Islam Indonesia.

Hanny, H., Agustina, L., Lingga, I. S., Rapina, R., Carolina, Y., Marpaung, E. I., ... Goiyardi, E. (2020). Analisis Pemetaan Profil Badan Usaha Milik Desa Serta Potensi dan Permasalahannya di 
Bidang Pengelolaan Air Bersih: (studi kasus di BUMDes Kertajaya, Cianjur, Provinsi Jawa Barat). Patria, 2(1), 8-24. https://doi.org/10.24167/patria.v $2 \mathrm{i} 1.2570$

Menteri Perindustrian dan Perdagangan RI. (2004). Keputusan Menteri Perindustrian dan Perdagangan Republik Indonesia nomor 651/MPP/ Kep/10/2004 Tentang Persyaratan Teknis Depot Air Minum dan Perdagangannya Menteri Perindustrian dan Perdagangan Republik Indonesia. Jakarta, Indonesia.

Munir, M., Saraswati, H, S. F., \& Rifa'i, Y. (2019). Study Kelayakan Bisnis dalam Aspek Lingkungan Hidup. Labatila: Jurnal Ilmu Ekonomi Islam, 3(1), 46-60.

Muqorobin, A. (2018). Analisis Kelayakan Usaha Air Minum dalam Kemasan Pada PDAM Tirta Bumi Sentosa Kebumen. The National Conferences Management and Business (NCMAB) 2018, 63-78.

Presiden Republik Indonesia. (2009). Undang-Undang Republik Indonesia Nomor 32 Tahun 2009 Tentang Perlindungan dan Pengelolaan Lingkungan Hidup. Jakarta, Indonesia, 1-39.

Presiden Republik Indonesia. (2014). Undang-Undang Republik Indonesia Nomor 6 Tahun 2014 Tentang Desa. Jakarta, Indonesia, 1-65.

Purnomo, R. A., Riawan, ., \& Sugianto, L. O. (2017). Studi Kelayakan Bisnis. Unmuh Ponorogo Press, 1-223.

Sofiah, E., \& Septiana, Y. (2017). Sistem Pendukung Keputusan
Feasibility Study Untuk Menilai Kelayakan Sebuah Bisnis. Jurnal Wawasan Ilmiah, 8(1), 18.

Tanaka, A. L., \& Marlina, M. A. E. (2017). Studi Kelayakan Bisnis Uniquephotocard Di Mal Ciputra World Surabaya. PERFORMA: Jurnal Manajemen Dan Start-Up Bisnis, 1(6), 746-754. 